\title{
Case of an intrahepatic sewing needle and review of the literature
}

\author{
Özgür Bostancı, M.D., Ufuk Oğuz İdiz, M.D., Muharrem Battal, M.D., \\ Cemal Kaya, M.D., Mehmet Mihmanlı, M.D.
}

Department of General Surgery, Şişli Etfal Training and Research Hospital, İstanbul-Turkey

\begin{abstract}
An intrahepatic foreign body (FB) is rarely observed. In most cases, object passes from the gastrointestinal tract to the liver via migration. Uncomplicated intrahepatic FB can be followed without surgical intervention; however, complicated intrahepatic FB requires laparoscopy or laparotomy. Presently described is laparoscopic operation on 22-year-old female patient who had incidental sewing needle in the right liver lobe. As there were initially no complications, follow-up monitoring was recommended. However, the patient subsequently complained of stomach pain and developed fever. Laparoscopic exploration located sewing needle in the right liver lobe lateral to the gall bladder with end of needle protruding from the liver. Needle was removed with laparoscopic grasper. Review of the literature regarding 23 other intrahepatic sewing needle cases is also presented.
\end{abstract}

Keywords: Foreign body; liver; sewing needle.

\section{INTRODUCTION}

Although swallowing of foreign body (FB) is a problem particularly observed in the pediatric population, it is also seen in adults. Gastrointestinal perforation occurs in less than $1 \%$ of patients. Intrahepatic FB is more rarely observed. Intrahepatic FB may enter the liver via direct penetration from the abdominal wall, via the bloodstream, or, most often, via migration from the gastrointestinal tract. ${ }^{[I]}$ Uncomplicated hepatic may be followed-up without requiring surgery. ${ }^{[2]}$ Endoscopy, ultrasonography, and abdominal tomography may help to arrive at diagnosis and plan treatment. ${ }^{[3]}$

\section{CASE REPORT}

A 22-year-old female patient with no previous abdominal surgery presented at polyclinic complaining of intermittent pain

Address for correspondence: Ufuk Oğuz İdiz, M.D.

Şişli Etfal Eğitim ve Araştırma Hastanesi, Genel Cerrahi Kliniği, İstanbul, Turkey

Tel: +90 212 - 3735000 E-mail: oguzidiz@yahoo.com

Qucik Response Code Ulus Travma Acil Cerrahi Derg 口ir.9 2017;23(I):77-80

doi: $10.5505 /$ tjtes. 2016.48995

Copyright 2017

TJTES in the abdominal right upper quadrant (RUQ) for 6 months. On examining the patient, abdominal RUQ was painful on palpation, defense and rebound were negative, and lung sounds were normal. Temperature was also normal at $37^{\circ} \mathrm{C}$. Blood examination revealed white blood cell (WBC) count of 9000/ $\mathrm{mm}^{3}$ (normal range: $4000-11000 / \mathrm{mm}^{3}$ ), C-reactive protein (CRP) was $3 \mathrm{mg} / \mathrm{L}$ (normal range: 0-6 mg/L), aspartate aminotransferase (AST) was $60 \mathrm{U} / \mathrm{L}$ (Normal range: 4-37 U/L), and alanine aminotransferase (ALT) was $53 \mathrm{U} / \mathrm{L}$ (normal range: 0-42 U/L). Ultrasonography revealed radiolucency in the right liver lobe adjacent to the gall bladder, which dictated need for computed tomography (CT). CT image suggested that object similar to radiopaque sewing needle was present in the right liver lobe adjacent to the gall bladder and protruded outside the liver (Fig. Ia). Due to absence of significant complication, initially, the patient was merely monitored closely. In first month, WBC and CRP values remained normal, AST was 65, and ALT was 58. In second follow-up month, because the patient had abdominal RUQ pain and WBC count of 13000/ $\mathrm{mm}^{3}$, CRP of $23 \mathrm{mg} / \mathrm{L}$, AST of $130 \mathrm{U} / \mathrm{L}$, ALT of $120 \mathrm{U} / \mathrm{L}$ and temperature was $38^{\circ} \mathrm{C}$, abdominal exploration was planned. Laparoscopic exploration located sewing needle in the right liver lobe lateral to the gall bladder with one end outside the liver (Fig. Ib). There were no abscesses or organ perforations in the abdomen. The end of the sewing needle was freed from the liver and needle was removed with laparoscopic grasper (Fig. Ic). The patient was discharged from the hospital with no complications on second postoperative day. No problem occurred during follow-up every week for I month. 

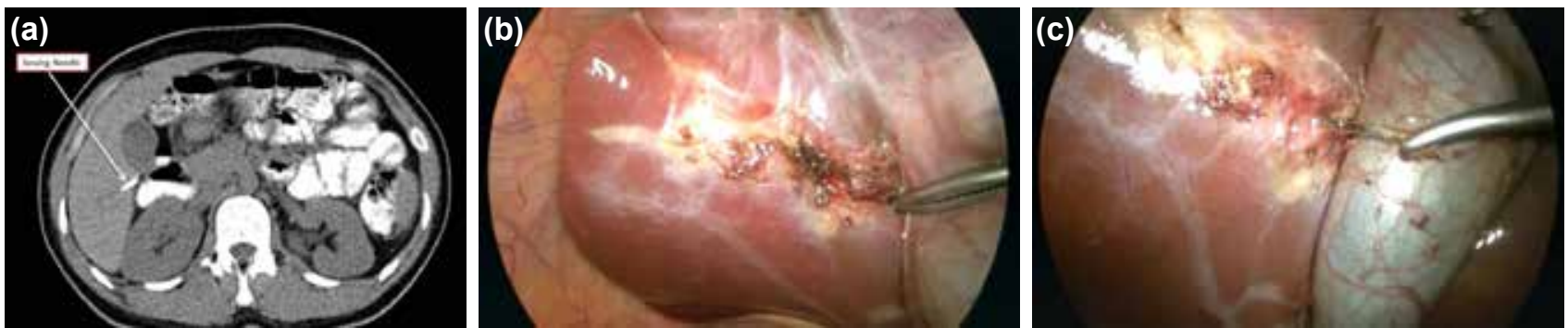

Figure 1. (a) Computer tomography of the liver before operation. (b) Sewing needle in the liver. (c) Appearance of the liver after removing the sewing needle.

\section{DISCUSSION}

Considering that FB in the liver is rarely seen, occurrence of sewing needle in the liver is even more rare. Review of the literature disclosed 23 cases to date ${ }^{[2,4-25]}$ (Table I). When blunt bodies are swallowed, conservative follow-up is generally sufficient. With respect to radiopaque $\mathrm{FBs}$, patients are monitored with weekly radiograph and regular stool examination. ${ }^{[26]}$ Despite the fact that most FBs are excreted from the body within 4 to 6 days, this period may extend to 4 weeks. When object is not excreted via stool within 3 to 4 weeks or if symptoms such as stomach pain, fever, etc., de- velop within this period, surgical or endoscopic intervention may be required. ${ }^{[27]}$

Uncomplicated intrahepatic FB can be monitored without surgical intervention; however, complicated intrahepatic FB requires laparoscopy or laparotomy. During surgical intervention, in addition to removing FB, abscess drainage or hepatic segmentectomy may be required in some cases. ${ }^{\left[{ }^{[1]}\right]}$

Gastrointestinal perforation due to swallowing FB is observed in less than $1 \%$ of patients. Other manifestations include peritonitis, localized abscess or inflammatory mass, bleeding, or

Table I. Summary of data from 23 cases of hepatic sewing needle

\begin{tabular}{|c|c|c|c|c|c|}
\hline & Sex & Age & Diagnosis & Location & Intervention \\
\hline Deveci, 2014 & Female & 15 years & Acute abdomen & Right lobe & Laparotomy \\
\hline $\mathrm{Xu}, 2013$ & Male & 5 months & Incidental & Right lobe & Laparotomy \\
\hline Incedayi, 2012 & Female & 52 years & Incidental & Left lobe & Laparotomy \\
\hline Bakal, 2012 & Male & 14 years & Acute abdomen & Right lobe & Laparotomy \\
\hline Bulakci, 20I I & Female & 22 years & Incidental & Right lobe & Laparoscopy \\
\hline Jutte, 2010 & Female & 45 years & Hepatic abcess & Undisclosed & Laparoscopy \\
\hline Bolonaki, 2010 & Male & 21 years & Acute abdomen & Left lobe & Laparotomy \\
\hline Senol, 2010 & Male & 27 years & Incidental & Undisclosed & No intervantion \\
\hline Dominguez, 2009 & Male & 3 years & Incidental & Left lobe & Laparoscopy \\
\hline Feng, 2009 & Female & 76 years & Incidental & Left lobe & No intervantion \\
\hline Avcu, 2009 & Female & 16 years & Acute abdomen & Right lobe & Laparotomy \\
\hline Saitua, 2009 & Undisclosed & 3 months & Incidental & Undisclosed & Laparotomy \\
\hline Lanitis, 2007 & Female & 35 years & Swallowing history & Left lobe & Endoscopy \\
\hline Azili, 2007 & Female & 14 years & Swallowing history & Right lobe & Laparotomy \\
\hline Le Mandat-Schultz, 2003 & Male & II months & Swallowing history & Right lobe & Laparoscopy \\
\hline Chintamani, 2003 & Male & 26 years & Hepatic abcess & Right lobe & Laparotomy \\
\hline Nishimoto, 2003 & Male & I year & Transcutaneous & Left lobe & Laparotomy \\
\hline Roca, 2003 & Female & 85 years & Swallowing history & Left lobe & No intervantion \\
\hline Rahalkar, 2003 & Female & 23 years & Swallowing history & Left lobe & No intervention \\
\hline Saviano, 2000 & Female & 65 years & Transcutaneous & Left lobe & Laparoscopy \\
\hline Crankson, 1997 & Male & 2 years & Incidental & Right lobe & No intervention \\
\hline Ward, 1978 & Female & 20 years & Swallowing history & Left lobe & Laparotomy \\
\hline Abel, I97I & Male & II months & Incidental & Left lobe & Laparotomy \\
\hline
\end{tabular}


fistula. ${ }^{[2,28]} \mathrm{CT}$, colonoscopy, and surgical exploration are all useful to examine FB in the gastrointestinal tract. ${ }^{[29]}$

According to the literature, presence of sewing needle in the right liver lobe has been documented in 9 cases and in the left liver lobe in II cases. In another 3 cases, localization was not specified. Twelve patients were female and 10 were men; II were under the age of 18 years and 12 were over 18 years of age. From a diagnostic perspective, 6 patients went to the hospital after swallowing needle without acute abdomen, 2 patients were diagnosed with liver abscess, ${ }^{[8,19]}$ and needle in the livers of 9 patients were diagnosed as incidental. Four patients were examined for acute abdomen, and FB in the liver was observed..$^{[4,7,9,14]}$ In I patient who had acute abdomen, the abdomen was explored with right paramedian incision. Intraoperatively, needle could not be seen or palpated from outside. Therefore, needle was located with the help of fluoroscopy, which indicated that needle was embedded nearly $\mathrm{I} \mathrm{cm}$ into the right hepatic lobe. It was exposed by opening the overlying liver parenchyma with electrocautery. ${ }^{[7]}$ Two patients evidently inserted the sewing needle transcutaneously into the liver. ${ }^{[20,24]}$

Treatment for sewing needle in the liver is based upon its location, displacement, and presence of symptoms or complications. No intervention was planned for any of the 5 asymtomatic cases which were diagnosed incidentally or had swallowing history. There were no complications on follow-up. [2,10,13,21,22] In case of a 76-year-old woman who was hospitalized due to complaint of fatigue, $X$-ray incidentally revealed metal needle in superior abdominal area. Ultrasound examination revealed $3.5 \mathrm{~cm}$-long, metal, needle-like object in the left lobe of the liver. Acupuncture had been performed on the abdomen more than 20 years previously. She had no abdominal pain and no operation was performed. The patient was followed-up for 2 years and the needle remained stable in the liver without any abdominal symptoms. ${ }^{[13]}$

Laparoscopic intervention was performed on 5 patients to remove $\mathrm{FB}$, while laparotomy was preferred for II patients. Bulakçı et al. reported case of a patient who had accidental ingestion of sewing needle in which gastroscopy and colonoscopy were performed 2 weeks after ingestion, but failed to locate the needle. CT scan was performed and they noticed that the needle had migrated from the duodenum to the liver. Because of moderate abdominal RUQ pain, laparoscopy was performed. Needle was then easily removed due to extracapsular migration. ${ }^{\left[{ }^{\prime \prime}\right]}$ In I patient who swallowed 2 needles, $I$ in the liver was removed with gastroscopy and the other with laparoscopy. ${ }^{[16]}$ In another case, patient had 2 surgeries. The swallowed needle was not found in the first operation, and the patient used antibiotherapy for inflammation. After 2 months, the patient had abdominal pain and underwent second operation. Sewing needle was easily found due to migration close to the gallbladder. ${ }^{[14]}$ Of the patients who required surgical intervention, 10 of 16 underwent surgery due to possible complications. In our case, the patient arrived at the hospital with no initial complications, but ultimately required laparoscopy 2 months later because of stomach pain and fever.

\section{Conclusion}

Although FB in the liver is rarely seen, when it does occur, it may progress with various complications. Thus, patients with uncomplicated, stable, sewing needle should be followed up with regard to possible complications.

Conflict of interest: None declared.

The authors further declare that they received no financial or editorial assistance.

\section{REFERENCES}

1. Lotfi M. Foreign body in the liver. Int Surg 1976;61:228.

2. Crankson SJ. Hepatic foreign body in a child. Pediatr Surg Int 1997;12:426-7. Crossret

3. Santos SA, Alberto SC, Cruz E, Pires E, Figueira T, Coimbra E, et al. Hepatic abscess induced by foreign body: case report and literature review. World J Gastroenterol 2007;13:1466-70. Crossret

4. Deveci U, Bakal Ü, Doğan Y. Foreign body in liver: sewing needle. Turk J Gastroenterol 2014;25:737-8. Crossre

5. Xu BJ, Lü CJ, Liu WG, Shu Q, Zhang YB. A sewing needle within the right hepatic lobe of an infant. Pediatr Emerg Care 2013;29:1013-5.

6. Incedayi M, Sonmez G, Gulec B, Yigitler C, Basekim C. A migrated sewing needle to the liver. JBR-BTR 2012;95:337. Crossref

7. Bakal U, Tartar T, Kazez A. A rare mode of entry for needles observed in the abdomen of children: Penetration. J Indian Assoc Pediatr Surg 2012;17:130-1. Crossret

8. Jutte E, Cense H. Liver abscess due to sewing needle perforation. ScientificWorldJournal 2010;10:1532-4. Crossre-

9. Bolanaki H, Kirmanidis MA, Courcoutsakis N, Tsalkidou EG, Simopoulos C, Karayiannakis AJ. Gastric penetration by an ingested sewing needle with migration to the liver. J Gastrointestin Liver Dis 2010;19:223-4.

10. Senol A, Isler M, Minkar T, Oyar O. A sewing needle in the liver: 6 years later. Am J Med Sci 2010;339:390-1. Crossret

11. Bulakçı M, Agayev A, Yanar F, Sharifov R, Taviloğlu K, Uçar A. Final destination of an ingested needle: the liver. Diagn Interv Radiol 2011;17:646.

12. Dominguez S, Wildhaber BE, Spadola L, Mehrak AD, Chardot C. Laparoscopic extraction of an intrahepatic foreign body after transduodenal migration in a child. J Pediatr Surg 2009;44:17-20. Crossret

13. Feng QZ, Wang J, Sun H. A sewing needle in liver: a case report and review of the literature. Cases J 2009;2:6520. Crossret

14. Avcu S, Unal O, Ozen O, Bora A, Dülger AC. A swallowed sewing needle migrating to the liver. N Am J Med Sci 2009;1:193-5.

15. Saitua F, Acosta S, Soto G, Herrera P, Tapia D. To remove or not remove...asymptomatic sewing needle within hepatic right lobe in an infant. Pediatr Emerg Care 2009;25:463-4. Crossre

16. Lanitis S, Filippakis G, Christophides T, Papaconstandinou T, Karaliotas C. Combined laparoscopic and endoscopic approach for the management of two ingested sewing needles: one migrated into the liver and one stuck in the duodenum J Laparoendosc Adv Surg Tech A 2007;17:311-4.

17. Azili MN, Karaman A, Karaman I, Erdoğan D, Cavuşoğlu YH, Aslan $\mathrm{MK}$, et al. A sewing needle migrating into the liver in a child: case report and review of the literature. Pediatr Surg Int 2007;23:1135-7. Crossre] 
18. Le Mandat-Schultz A, Bonnard A, Belarbi N, Aigrain Y, De Lagausie P. Intrahepatic foreign body laparoscopic extraction. Surg Endosc 2003;17:1849. Crossree

19. Chintamani, Singhal V, Lubhana P, Durkhere R, Bhandari S. Liver abscess secondary to a broken needle migration-a case report. BMC Surg 2003;3:8. Crossre

20. Nishimoto Y, Suita S, Taguchi T, Noguchi S, Ieiri S. Hepatic foreign body - a sewing needle - in a child. Asian J Surg 2003;26:231-3. Crossret

21. Roca B. A sewing needle in the liver. South Med J 2003;96:616-7. Crossre.

22. Rahalkar MD, Pai B, Kukade G, Al Busaidi SS. Sewing needles as foreign bodies in the liver and pancreas. Clin Radiol 2003;58:84-6. Crossre.

23. Abel RM, Fischer JE, Hendren WH. Penetration of the alimentary tract by a foreign body with migration to the liver. Arch Surg 1971;102:227-8.
24. Saviano M, Melita V, Tazzioli G, Farinetti A, Drei B. Videolaparoscopic removal of a foreign body from the liver. Eur J Surg 2000;166:744-6.

25. Ward A, Ribchester J. Migration into the liver by ingested foreign body. Br J Clin Pract 1978;32:263.

26. Spina $P$, Minniti S, Bragheri R. Usefulness of ultrasonography in gastric foreign body retention. Pediatr Radiol 2000;30:840-1.

27. Jecković M, Anupindi SA, Barbir SB, Lovrenski J. Is ultrasound useful in detection and follow-up of gastric foreign bodies in children? Clin Imaging 2013;37:1043-7. Crossre

28. Ngan JH, Fok PJ, Lai EC, Branicki FJ, Wong J. A prospective study on fish bone ingestion. Experience of 358 patients. Ann Surg 1990;211:459-62.

29. Lee KF, Chu W, Wong SW, Lai PB. Hepatic abscess secondary to foreign body perforation of the stomach. Asian J Surg 2005;28:297-300. Crossret]

\section{OLGU SUNUMU - ÖZET}

\section{Karaciğer içerisinde dikiş iğnesine ait olgu sunumu ve literatür derlemesi \\ Dr. Özgür Bostancı, Dr. Ufuk Oğuz İdiz, Dr. Muharrem Battal, Dr. Cemal Kaya, Dr. Mehmet Mihmanlı}

Şişli Etfal Eğitim ve Aratırma Hastanesi, Genel Cerrahi Kliniği, İstanbul

İntrahepatik yabanci cisimler nadir olarak gözlenir. Birçok olguda gastrointestinal kanaldan migrasyon ile karaciğere geçiş olmaktadır. Komplike olmayan intrahepatik yabanci cisimler cerrahi müdahaleye intiyaç duyulmadan takip edilebilirler. Komplike olmuş intrahepatik yabanci cisimlerde ise laparotomi veya laparoskopi ile cerrahi müdahaleye gerek duyulabilmektedir. Bu olgu sunumunda karaciğerde insidental olarak dikiş iğnesi saptanmış 22 yaşındaki kadın olgu komplikasyonu olmadığı için takibe alındı. Takipleri sırasında karın ağrısı ve aralıklı ateş şikayetleri gelişti. Laparoskopik olarak eksplore edilen hastada karaciğer sağ lob lateralinde hemen safra kesesi komşuluğunda bir ucu karaciğerden dışarıda olduğu gözlenen dikiş iğnesi laparoskopik grasper ile çıkarıldı. Bu olgu sunumu ile birlikte literatürde bulunan 23 benzer olgu da irdelendi.

Anahtar sözcükler: Dikiş iğnesi; karaciğer; yabancı cisim.

Ulus Travma Acil Cerrahi Derg 2017;23(I):77-80 doi: 10.5505/tjtes.2016.48995 